Glow, Hilary, Kershaw, Anne and Reason, Matthew ORCID: https://orcid.org/0000-0003-0536-4236 (2020) Leading or avoiding change: the problem of audience diversification for arts organisations. International Journal of Cultural Policy.

Downloaded from: http://ray.yorksj.ac.uk/id/eprint/4353/

The version presented here may differ from the published version or version of record. If you intend to cite from the work you are advised to consult the publisher's version: https://www.tandfonline.com/doi/full/10.1080/10286632.2019.1709060

Research at York St John (RaY) is an institutional repository. It supports the principles of open access by making the research outputs of the University available in digital form. Copyright of the items stored in RaY reside with the authors and/or other copyright owners. Users may access full text items free of charge, and may download a copy for private study or non-commercial research. For further reuse terms, see licence terms governing individual outputs. Institutional Repository Policy Statement

\title{
RaY
}

Research at the University of York St John

For more information please contact RaY at ray@yorksj.ac.uk 


\section{Leading or Avoiding Change: the problem of audience diversification for arts organisations}

Abstract

Despite years of concern and various attempts to address the issue, arts audiences remain persistently white, educated, middle class and middle-aged. The homogenous profile of arts attenders undermines the public value of subsidised arts organisations, arguably calling into question the creative vibrancy of the sector and threatening its sustainability. Diversifying audiences has traditionally been the role of audience development programs. However a recent shift has brought attention to the influence of organisational practice: as Lindelof observes, 'it is not the audience, but the institutions that are in need of development' (2015, p. 203). The lack of audience diversity may be evidence of implicit cultural policy within arts organisations which restricts practices that would result in changes to the profile of audiences.

Building on the work of Harlow (2014) this article presents a new conceptualisation of the organisational work that is required if the goal is to diversify audiences. Drawing on two case studies, it identifies a spectrum of approaches to the organisational changes required to diversify audiences. Our organisational study identifies the current strengths and weaknesses of arts organisations in relation to audience diversification processes, highlighting opportunities for future cultural policy at both a government and institutional level.

Keywords: audience development, audience diversity, organisational change, public value

\section{Disclosure statement}

This article draws on data collected through an evaluation project that was funded by a consortium of arts organisations. Two of the authors were contracted by the consortium to undertake this evaluation. The program that was evaluated forms one of the case studies examined in this article. 


\section{Introduction}

The homogeneity of arts audiences in Anglophone countries, and more broadly, has been a notable issue for arts/cultural organisations, and policy makers for many decades. That audiences remain predominantly white, middle class and middle-aged not only limits the public value of arts organisations but calls into question the capacity of cultural policy regimes to mandate change to ensure the relevance and cultural vitality of the creative sector. While government policy makers across Anglophone countries have attempted to address this issue through both implicit and explicit policy directives, little change has been observed in the social profile of audiences. Recent scholarship (Harlow 2014; Lindelof 2015) suggests that the lack of diversity within arts audiences is the result of limited organisational capacity and resistance to change.

This current research brings an organisational behaviour approach to the vexed issue of changing the social profile of arts audiences. It examines the organisational practice required by audience development initiatives that aim to diversify audiences. To this end, our research presents an organisational behaviour study of two cases of arts organisations that have sought to diversify their audiences: one to change the cultural background profile of audiences and artists, the other to change the disability profile of both audiences and programming. Our research found that while organisations claimed that audience diversification was a priority, and that they were making organisational changes to bring in new and diverse audiences, in most instances these changes were only partial alterations to established forms of practice and insufficient to deliver the looked-for results.

The study found evidence of a range of approaches and practices across organisations. Some of this variety of organisational approach and practice may reflect the specific art form and industrial contexts in which the organisations are working. However, the researchers found that across the phases of the Culture Cycle (creation, production, dissemination, 
exhibition and consumption) (UNESCO Institute for Statistics 2009) the approaches were generalizable, comparable and amenable to a taxonomic analysis. This led to our first research question: What are the generalizable characteristics of organisational practice designed to change the social profile of audiences?

A further finding was that some organisations were much more successful than others in changing their practices in order to achieve new levels of audience diversification. Using an organisational survey, we investigated the successes and failures of organisations undertaking organisational change directed to diversification. The results of the survey suggested that some of the organisations took explicit action demonstrating that they were able to embrace organisational change; others showed signs of (sometimes reluctant) adaptation, and some were, at some level, avoiding an audience-focused approach. This finding led us to our second research question: What drives and inhibits the practices of arts organisations that seek to diversify their audiences?

\section{A Policy Problem}

Diversifying the social profile of audiences according to cultural background, age, disability, class and geography is of interest to both government and the arts/culture sector. In particular, the need to diversify audiences and increase access is a priority in cultural policy, not only across Anglophone countries but internationally (for example Creative Europe 2018; Kong 2012; Lindelof 2015; Yúdice 2018). Of particular concern is the need to attract audiences that fall outside the dominant cultural norm and that represent national demographic averages.

At an international level participation in arts and culture is enshrined in Article 27 of the Universal Declaration of Human Rights (United Nations 2015), and the safeguarding of diverse arts and culture through UNESCOs Convention on the Protection and Promotion of the Diversity of Cultural Expressions (UNESCO 2005). Examples of national level policy 
commitments to the diversification of audiences include the Arts Council England's Creative Case for Diversity (Arts Council England 2018), and the Arts Council of Canada's Strategic Plan 2016-2021 with its commitment to: 'Increase support to artists, collectives and organizations striving for artistic excellence and greater engagement in the arts by an increasingly diverse public' (Canada Council for the Arts 2016). Policy commitments to audience diversification can also be seen in funding programs such as Creative New Zealand's Auckland Diversity Project fund (Creative New Zealand 2015) and the requirement for UK National Portfolio Organisations (NPOs) to report on the diversity of their audiences. Arts Council attention to audience diversity is also evident in research reports such as the Australia Council for the Arts' Arts Nation report (Australia Council for the Arts 2015) and numerous discussions and reports promoted by Americans for the Arts (Americans for the Arts 2019).

The UK policy response to the need to diversify audiences is part of a larger strategy to diversify both production and consumption in the cultural sector. Achieving greater diversity is described by the DCMS (Department for Digital, Culture, Media \& Sport) white paper as having been 'a problem for many years. While progress has arguably been made on addressing gender balance and LGBT representation within the cultural sectors, there remains some way to go; and the overall figures on diversity do not reflect national averages' (Department for Culture 2016, p. 26). Diversity is seen as an opportunity to the benefit of 'the art, the audiences, and the workforce and leadership' (Arts Council England). To this end, the Arts Council allocated 'diversity focused' strategic funds which has seen more than $£ 11.8$ million invested in the arts and cultural sector to facilitate greater levels of 'diverse led' NPOs (Arts Council England 2018). In particular, there is a call for clearer pathways into the cultural sectors for 'people from black and minority ethnic groups and for disabled people' 
(Department for Culture 2016, p. 26). As a means to prompt direct action, the UK's Creative Case for Diversity ties progress on enhanced diversification to future funding:

The government expects all museums, theatres, galleries, opera houses and other arts organisations in receipt of public money to reach out to everyone regardless of background, education or geography. We are challenging arts and cultural organisations to work even harder to make sure the most disadvantaged in society have greater opportunities to access culture. We will work with Arts Council England to ensure that every single cultural organisation that receives taxpayers' money contributes to fulfilling this duty. And they will report on progress made (Department for Culture 2016, p. 23).

The UK policy statements articulate a sense of deep frustration after many years of trying to address this problem. The solution it proposes is the current top-down policy and funding strategy which takes a directive (and potentially punitive) approach with the unmistakable implication that change, if and when it happens, will be policy-led.

In Australia, the policy response at a national level is highlighted in the Australia Council for the Arts Cultural Engagement Framework (Australia Council for the Arts 2016) which takes as its priority areas: First Nations peoples; children and young people; cultural diversity; older people; people with disability; and regional and remote Australia. Diversity is presented in this framework as a driver of vibrancy and innovation in cultural offerings as well as increased access to the arts. This policy direction followed the Australia Council's signing, in 2009, the UNESCO Convention on the Protection and Promotion of the Diversity of Cultural Expressions. Cultural diversity is seen as 'an essential requirement of sustainable development, because a world where diversity flourishes increases the range of choices for people and communities, thus nurturing their capacities for creativity and innovation' (Mar \& Ang 2015, p. 4). Mar \& Ang identify three distinct approaches to policy and funding initiatives to promote diversity in the Australian arts and cultural sector: community based approaches by which minority artists/audiences are encouraged to participate in cultural life 
with the policy goal of enhancing cultural democracy; artist-mediated approaches which emphasise the generation of innovative work to extend culturally diverse expressions with the policy goal of fostering cultural innovation; and industry based approaches supporting organisations which promote diverse cultural expression through advocacy, networking and capacity building with the goal of cultural sustainability (2015: 6).

The differences between the two policy approaches are telling: the UK is expecting all publicly funded arts/cultural organisations to become accountable and deliver results; it is the responsibility of every part of the sector to diversify the workforce, the arts that is produced, and the audience. Australia, on the other hand, is funding designated activities and organisations; diversification is activity-led, rather than a policy-led mandate. The UK takes a direct top-down interventionist approach, while Australia takes a more grounded one expecting that goals around cultural democracy, innovation and sustainability will be delivered through activities and programs on the ground with diversity as their primary goal.

The policy approach that proves to be the most effective will only become evident in hindsight. Regardless of the policy approach, the problem lies with the organisational responses to the injunction (in the UK's case) or the encouragement (in the Australian case) to build capacity in terms of greater levels of diversity. This paper focuses specifically on the task of diversifying arts audiences and argues that this a complex and multi-dimensional task for which many of the organisations in our case study did not evince much readiness or capacity. This lack of a sophisticated understanding of how to diversify audiences will severely limit the possible (and hoped for) outcomes of either the UK or Australian policy strategies.

\section{A Problem in Practice}

Diversifying audiences - which is the aim of many audience development initiatives -is one 
of the most significant tasks facing contemporary arts organisations. There is now a rich body of evidence that audiences for many mainstream arts practices are aging and in decline (Brown 2013; Lindelof 2015; National Endowment for the Arts 2015). The need to diversify audiences has vexed the sector for many years (Bennett \& Frow 1991; DiMaggio \& Useem 1978). For Lindelof the notion of audience development epitomises 'current dilemmas in theatres, concert halls and museums across the world' and represents 'the financial, artistic, social and educational aspects of institutional efforts to address the audience in new ways' (2015, p. 202).

Audience development refers to the nexus of programming, education and marketing, with the aim of broadening, deepening or diversifying arts audiences (Kawashima 2006; Mc Carthy \& Jinnett 2001; Parker 2012; Wiggins 2004). Within the scholarly literature audience development is problematized (Lindelof 2015) and instances of best practice are identified and explored (see for example Nightingale 2007). This article contributes to audience development theory, but with an emphasis on audience diversification; altering the dominant social profile of audiences and attracting those that are currently non-attenders.

Diversifying audiences - altering the social profile of audiences and attracting those that are currently 'non-attenders' - has been the focus of much audience development work (Lindelof 2015, p. 202). As Kawashima (2006) identifies, arts organisations generally address this problem by means of a 'product-led' approach using marketing techniques in an attempt to overcome psychological barriers to attendance.

Linked to the issue of audience diversification is the movement towards democratisation of the arts as identified in the 2001 RAND Report (Mc Carthy \& Jinnett 2001) whereby the notion of an audience, simply defined by attendance at an arts event, has been broadened to encompass a spectrum of arts participation activities. A common distinction is made between receptive and active (or participatory) engagement in the arts 
(Australia Council for the Arts 2010b; Brown \& Novak-Leonard 2011). Enhancing audience or public participation in the arts has more recently come to be understood as audience engagement which, as Conner suggests, 'signifies some type of emotional or affective relationship between consumer and arts event and/or arts organisation' (2013, pp. 2-3). The goal of enhancing audience/public engagement is now a commonplace objective of arts organisations and arts projects in Australia (Australia Council for the Arts 2015, 2016), in the UK (Walmsley 2016), Northern Europe (Lindelof 2015), and the US (Conner 2013; Kemp \& Poole 2016).

Yet there appears to be a dissonance between these stated policy directions and the capacity or readiness of arts organisations to realise such goals. Conner notes, for example, in the US even those arts organisations and practitioners who are 'energised by rising audiencecentred hermeneutic practices, don't know how to facilitate those practices, how to participate in them, or even get out of the way of them' $(2013$, p. 3).

The sector's long-standing difficulty in attracting non-attenders and diversifying the profile of arts audiences indicates that for audience development to be successful, it requires change in the operations of arts organisations (Harlow 2014). A commitment to audience diversification requires new forms of practice; arts organisations need to identify the issues in their current ways of working and seek new ways of operating in response to this critique (DiMaggio \& Powell 1983). Organisational responses will also need to be multifaceted and take a whole-of-organisation approach. Ostrower's survey of cultural participation and motivation in the US warns, for example, that while there is some evidence that audiences with African American and Hispanic cultural backgrounds show a preference for participating in works that celebrate heritage, 'organisations cannot expect that merely presenting isolated events that address cultural heritage will automatically increase attendance by African Americans and Hispanics...' (2005, p. 10). The issue of audience 
diversification is not adequately addressed by repackaging existing arts product which may be regarded as having a colonialist intention, expecting others to enjoy and appreciate what is implicitly positioned as the 'best' in arts. Rather, arts organisations need to develop a strategic approach 'built on an understanding of the audience they wish to reach and the multiple reasons that African Americans, like other groups, attend' (Ostrower 2005, p. 17).

Greater audience diversity is also required to demonstrate the public value of subsidised arts organisations. Public value acknowledges the common good that results from the work of strategically and entrepreneurially managed arts organisations (Moore 1995; Moore \& Benington 2011). It identifies that publically funded organisations service both 'upstream' (government and funding bodies) and 'downstream' (services users and the body politic) audiences (Wensley \& Moore 2011), while highlighting the role of audiences as 'legitimators and testimonial providers' of the receipt of public value (Bovaird \& Loeffler 2012, p. 1122). An underlying cause of the challenges facing the sector is poor public assessment of the value the arts (Croggon 2016; Holden 2006; Moore \& Moore 2005). Hence the current interest in audience development is accompanied by concern with issues such as social inclusion (Kawashima 2006) and artistic vibrancy (Australia Council for the Arts 2010a).

\section{Method}

This research was conducted over two phases Phase 1 involved the case study of a major Australian performing arts festival that aimed to increase collaborations between Australian and Asian artists as well as to diversify the cultural profile of participating audiences. This case study was examined to identify the generalisable characteristics of organisational practice designed to change the social profile of audiences (RQ1). It involved an abductive research strategy which drew on both existing theory and empirical data collected for this 
case study (Alvesson \& Skoldberg 2010; Dubois \& Gadde 2014). Phase 2 introduced a second case study in the form of a UK initiative that aimed to develop audiences and artists with a focus on learning disability. The two case studies provided a range of embedded cases (Yin 2009) in the form of individual organisations. These were examined to investigate the drivers and inhibitors of organisational practice designed to diversify audiences (RQ2). The design of this two phase case study is outlined in Table 1.

The two case studies examined in phase 2 of this research enable comparison of the different policy contexts which inform audience diversification initiatives in Australia and the UK. They also enable investigation of the audience diversification model with regard to two different aspects of the social profile of audiences: cultural background (Australian case study) and learning disability (UK). The Australian Asian performing arts festival (examined in both phases 1 and 2) involved a consortium of venues and arts organisations and aimed to build new and diverse audiences for Asian influenced performing arts as well as support new collaborations between Australian and Asian artists. This consortium had limited history of collaboration prior to the festival. Two of the authors were contracted to evaluate the festival, work which resulted in the Leading Change Audience Diversification Model. The UK case study was an initiative led by a major learning disability arts organisation and involved collaboration between organisations to increase the diversity of audiences and artists with a learning disability. The third author was voluntarily involved in evaluation of this initiative and employed the Leading Change Audience Diversification Model in the research.

The Australian case study examined in phase 1 involved narrative research, focus groups and desk research. Narrative interviews (averaging 45 minutes) were conducted with festival coordinators, venues, participating arts organisations, funding bodies and stakeholders. These interview participants were selected to allow investigation of the broader 'cultural ecology' (Brown \& Novak-Leonard 2011) involved in the design, planning and 
implementation of the festival. Focus groups (averaging 90 minutes) were held with three categories of staff from participating arts organisations: marketing, education and programming/ creative producers.

The Australian and UK embedded cases examined in phase 2 were selected in two ways. The Australian cases were purposively selected to profile the range of organisations that participated in the festival. All six organisations involved in the UK case study were invited to be involved in the research, the four cases are those that agreed to participate. The embedded cases were examined through data collected through narrative interviews (averaging 45 minutes) and organisational surveys (conducted online for the Australian case study and through narrative interview for the UK case study).

Insert Table 1 about here

\section{Findings and discussion}

\section{Characteristics of organisational practice designed to change the social profile of audiences}

\section{Research Findings}

Our abductive analysis of the Australian Asian performing arts festival case study resulted in new insights into the organisational practice needed to diversify audiences. We refer to this new conceptualisation as the Leading Change for Audience Diversification model. Building on Harlow's Nine Effective Practices of Audience-Building Programs (2014) the aim of our new model is to provide the arts sector with a guide to the work required to shift the dominant social profile of arts audiences and identify organisational readiness and capacity to undertake this change. In this section we outline the existing theory and empirical data on 
which our eight stage Leading Change for Audience Diversification model is built. Given these findings are drawn from a case study which aimed to change the cultural background of audiences they emphasise diversity in terms of ethnicity. In the second phase of research we consider the value of this model according to other social characteristics.

Stage 1: Recognise the need for change

Insights into the difficulties facing the arts sector in changing the social profile of audiences can be found in institutional theory. Institutional theory proposes that organisations strive to follow the models and expectations of their profession or sector, regardless of the strategic value or practicalities of these ways of working (Meyer \& Rowan 1991). The mechanisms by which this conformity is achieved are referred to as an institutional logic or template (Battilana, Leca \& Boxenbaum 2009; DiMaggio \& Powell 1983). The homogenous nature of arts audiences may therefore be the result of arts organisations adhering to institutional logics; ways of working which have been accepted and entrenched by their field but may not be practical or offer strategic advantage (Greenwood, Hinings \& Suddaby 2002; Greenwood, Hinings \& Whetten 2014; Lawrence 1999; Suddaby \& Greenwood 2005). One means of shifting these institutional logics or templates is stimulating organisational change through external 'jolts' which destabilise established practice, and facilitate the introduction of new ideas and the possibility of change, and innovation at an organisational level (Greenwood, Hinings \& Suddaby 2002). Stage 1 (see Table 2 below) in our audience diversification model is therefore to recognise the need for change as it is only through this recognition that organisational practice will shift away from existing institutional logics. A respondent from our study commented: 'The people I see up on Swanston St, I'm not seeing them in my theatre. So I don't think the Asian community are coming to the [theatre] ... It may take 10 years, but if we make [the arts organisation] a very open place where they feel welcome then we can start to develop the stories in parallel' (CO1). The comment signifies a 
recognition of the inevitability of change and the responsibility of the organisation to respond to it.

Stage 2: Identify target audience The audience development literature provides an important context for this research particularly in its focus on target-led marketing. The target-led or customer focused approaches to arts marketing are based on detailed knowledge of audiences and designed to appeal to their core values, lifestyles and interests (Bernstein \& Kotler 2006; Boorsma 2006). This target-led approach has traditionally been the focus of audience development initiatives that aim to appeal to non-traditional arts audiences and overcome the cultural dimension of social exclusion/ inclusion (Kawashima 2006). Kawashima argues that when attempting to diversify arts audiences it is 'imperative that cultural marketing turns to the "target-led" approach' (2006, p. 68). A respondent in our study discussed this issue: 'One of the things we do is audience-first programming in everything we do. We try to understand who our existing audience and our potential emerging audiences are, and then try to bring the right skills and resources into the organisation to attract those emerging audiences. Our ambition for this particular project was that we wanted to attract the Indian community with our Indian expats, second generation migrants and students' (CO2). The quotation underlines, for this organisation, the connection between audience-led programming and the specific effort to bring in new /underrepresented audiences by developing a nuanced understanding and definition of what was meant by 'Indian community'.

Stage 2 in the model proposed here acknowledges the importance of identifying the target audience as a critical step in the process of diversifying audiences. The benefit of this approach, as opposed to solely product-led marketing, is well established as a mechanism for ameliorating the social exclusion of under-represented audiences.

Stage 3: Research audience and their barriers to participationAddressing the lack of diversity within arts audiences requires attention to the tangible and intangible barriers to arts 
participation (Kawashima 2006). Various audience development models have considered the impact of social, cultural, behavioural and psychographic factors on arts engagement. McCarthy and Jinnett (2001) present a model that considers the decision making process required to participate in the arts, and highlight an audience member's background, perception, practical situation and experience as critical factors in the decision making. Wiggins (2004) proposes a model that draws on the motivation/ opportunity/ ability consumer behaviour model.

Stage 3 in our model proposes that organisations need to research audiences and the barriers to participation that are specific to the target audience and the nature of the cultural product which the arts organisation is offering. A respondent in our study noted: 'We did a big research project two years ago about the barriers to entry, and how we could open up to new audiences. It taught us that we do need to take a hands-on and collaborative approach. So it's more like community development work ... instead of doing the programming in place, and sending it out to audiences, [we're] doing that collaborative engagement work to think about which audiences we want to identify, and how we can bring them into the festival' (CO6). In considering barriers to participation, the quotation indicates the need for research, collaboration, and outreach to achieve good practice.

Stage 4: Programming is responsive to target audience The Harlow (2014) audience development model on which this research builds gives no attention to programming. As such it takes an approach that protects the core product of an arts organisation (Kawashima 2006). The Harlow model suggests an alignment with a product-led approach and the belief that 'the artistic product does not exist to fulfil a market need. ... Instead of seeking to meet consumers' needs by offering them a product they desire, the arts manager seeks consumers who are attracted to the product (Colbert 2003, p. 31). 
In considering the role of programming, a respondent in our study explained: 'When [Asian performing arts festival] first appeared on the landscape ... we wanted to see if we could bring Jaipur Literary Festival to Australia for the first time ... but also we wanted to bring in a Programme Producer who would specifically help us to programme and deliver it to a diverse Indian diaspora community' (CP6). . This response led to Stage 4 of the audience diversification model which proposes that programming has to be responsive to the target audiences. This stage is one that integrates product- and target-led approaches to arts marketing (Hill et al. 2018) and proposes a more fundamental change than minor adjustments to the packaging and presentation of usual arts offerings (Kawashima 2006). Included in this model is the potential for programming to embrace a range of alternative platforms, including digital content (Moffat \& Turpin 2018). It calls for a review of the core product of an arts organisation, but without the need to compromise artistic quality (Kawashima 2006, p. 67). In fact being responsive to diverse audiences is likely to enhance artistic vibrancy (Australia Council for the Arts 2010a) and result in work that is 'relevant', 'energetic' and 'resonates' (Mar \& Ang 2015).

\section{Stage 5: Develop relationship and connections with target audience}

The interrogation of how to develop relationships with target audiences is usefully informed by some of the scholarship around cultural intermediaries. Dynamic and innovative organisations are able to access and utilise resources from outside their organisation (Ambrosini \& Bowman 2009; Teece, Pisano \& Shuen 1997). This requires organisations to work in alliances and networks (den Hertog, van der Aa \& de Jong 2010). Innovative arts organisations are therefore able to establish relationships with external actors and groups (Greer, Lusch \& Vargo 2016; Pérez-Nordtvedt et al. 2008) such as target audiences and communities. 
A respondent in the study commented: 'In terms of Indigenous audiences for the festival we employed an Indigenous publicist to promote to community to get discounts and community nights for shows and also bring a number of groups along to artist talks. Both of our producers are also Indigenous. And there are all sorts of secret groups on Facebook and networks that we don't know about that they were able to easily access' (CO5). The comment speaks to the various points of entry to the organisations for Indigenous community members through the publicist, the producers and social media.

As underscored by this comment, in arts organisations the work of developing relationships with target audiences can be driven by cultural intermediaries (Bourdieu 1984; Durrer \& Miles 2009; Featherstone 1991) or cultural brokers (Kurin 1997) who are skilled in forming relationships outside the organisation. Cultural brokers have unique interpersonal skills that are valuable resources and they use these skills to initiate new and innovative forms of practice. Stage 5 in the process of diversifying audiences proposed here acknowledges the importance of developing relationships with the target audience and building multiple connections between the audience and the arts organisation. This is reinforced by the evidence that cultural intermediaries drive organisational change through their capacity to function as institutional entrepreneurs (Battilana \& Leca 2009) and through the dynamic capabilities they bring to service innovation (den Hertog, van der Aa \& de Jong 2010).

\section{Stage 6: Gain broad organisational commitment to audience development}

The effort to drive organisational change is also discussed in the strategic management literature which sees the achievement of broad organisational commitment to change as a vital part of building dynamic capabilities. Drawing from the service innovation field, den Hertog et al note that the process of realising an innovative service often requires a multidisciplinary project team which secures the support of senior management and ensuring 
the 'offering [is] understood by colleagues, external partners and recognised by clients as a useful, valuable new service offer' (den Hertog et al 2010:501). A strategic commitment leading to organisational change needs to be broadly encouraged and supported in an environment that 'values experimentation, prototyping and thinking out of the box' (2010:501).

This was noted by one of the respondents: 'I suppose [the Artistic Director] initially and then our whole staff team were really driving it with our board and stakeholders.... Increasing our cultural engagement with Asia and Asian authors is part of our business plan. It's one of our key strategic goals that we're working towards, and have been working towards over the past couple of years' (CO6). Stage 6 of the audience diversification model proposes that meaningful change can only occur when there is broad organisational commitment to the project of audience development. The respondent quote here supports this view that change and innovation are not only matters for the whole organisation, but have to be explicitly articulated in its broad strategic thinking.

\section{Stage 7: Undertake evaluation and reflective practice}

Further to a broad strategic commitment, organisational change processes also require a commitment to evaluation. This is well-recognised in the strategic management literature on the dynamic capabilities of organisations which, for Ambrosini and Bowman, are the mechanisms by which organisations learn, and develop new skills and capabilities (2009: 30). Helfat et al (2007) describe the dynamic capabilities of an organisation as the capacity to adapt its base of processes and resources, including knowledge, in response to changes in the environment (Helfat et al., 2007). Evaluation and reflective practice is a feature of the learning that happens in dynamic organisations as they allow: 'tasks to be performed more effectively and efficiently as an outcome of experimentation, reflecting on failure and success' (Ambrosini and Bowman 2009: 35). 
In our model, Stage 7 proposes that organisations undertake evaluation and reflective practices on the basis that this is a critical part of organisational learning and the development of ideas and practices around audience building. This was exemplified by a respondent who commented: 'Rather than give people a set of tick boxes, we felt that there was an opportunity to ask people: how do you identify yourself in terms of your cultural background or your ethnicity, and people could write whatever they wanted. People really gave you a whole picture of how they see themselves and therefore why they are at this event' (CO6). The quotation underlines a learning approach in which processes are adapted (from tick box surveys to open ended questions) in order to develop an increasingly nuanced understanding of audiences and their evolving subjectivities.

\section{Stage 8: Change the organisation's usual way of operating}

To change the social profile of arts audiences, the institutional logics and templates that shape practice in the arts sector will need to be altered (as discussed above under step 1). The stimulus for these changes may be practice driven (Smets, Morris \& Greenwood 2012) or a process whereby new modes of operating are theorised and diffused across the field (Greenwood, Hinings \& Suddaby 2002). Whichever approach is adopted, it is likely to meet with a measure of organisational discomfort, as noted by a respondent: 'It should feel uncomfortable for the organisations that are taking part. It should be a stretch because that suggests that it's always providing an opportunity to do something that's different and tricky and involves trying to do a different thing' (CO6).

The 8th and final stage of the model proposes that audience diversification has to entail changes to the organisation's usual way of operating. If a commitment to the diversification of audiences is to be embedded into the arts sector, new forms of practice need to be accepted and become commonplace at an individual, organisational and field level. This 
will involve ongoing changes to the strategic and operational practices of arts managers and organisations.

Ambrosini and Bowman take a strategic management perspective in accounting for how organisations change over time, taking a 'dynamic capability perspective' which focuses not simply on an organisation's resources but analyses the mechanisms by which organisations learn, and develop new skills and capabilities (2009: 30). The dynamic capability perspective addresses an organisation's ability to integrate, develop, reconfigure, and understand the necessary internal and external competences that are required to sustain and grow performance in the context of a rapidly changing environment. On the flipside organisations may be embattled by, what Ambrosini and Bowman call, 'core rigidities' which are organisational approaches which 'inhibit development, generate inertia and stifle innovation' (2009: 32). The current research provides an example of a rapidly changing environment in which the fact of demographic changes within the general Australian and UK population are not reflected in performing arts audiences and, further, that many arts organisations are dealing with 'core rigidities' which prevent them from reconfiguring their capabilities to meet a changing world.

Based on the above discussion, our eight-stage organisational change model that aims to diversify audiences is presented in Table 2 below.

Insert Table 2 about here

To investigate the practice of the organisations involved in the Australian Asian performing arts festival we mapped narrative data from the embedded case studies against the Leading Change for Audience Diversification model to determine its relevance to the work done by arts organisations that participated in the festival. The results of this mapping are presented in Table 3. 
Insert Table 3 about here

The Leading Change for Audience Diversification model enables us to determine firstly, the extent to which the diversification of audiences informs organisational practices, and secondly, where diversification is a priority, how it manifested. Narrative interviews and focus groups indicated most of the organisations involved in the festival were in the early stages of the organisational change required to successfully diversify arts audiences. The two stand out cases were the Contemporary Performance (CO5) and the Literary Festival (CO6), both of which presented evidence of having undertaken the eight organisational change steps required to successfully commit to the diversification of audiences. In these cases audience development informs multiple levels of organisational practice.

The stages of work required to diversify audiences which were most overlooked in the case studies were: researching audiences and their barriers to attendance, gaining broad organisational support for audience development; and undertaking evaluation and reflective practice.

From this analysis emerged a spectrum of approaches to the Leading Change for Audience Diversification model (Table 4). We have developed the following three points along the spectrum:

1. Leader: this signifies the organisation is programming for new audiences and building new relationships;

2. Adaptor: this category typifies organisations which tend to offer programs for known audiences and existing stakeholders; and

3. Avoider: this category identifies organisations which do not primarily think about audiences and is artistic product-led. 
Insert Table 4 about here

Our typology which identifies a spectrum of arts organisations from 'Leaders' through 'Adaptors' and 'Avoiders' is a further development of the discussion around dynamic capabilities. Organisations which fall into the Leader category are those that are developing their adaptive and dynamic capacities in recognition of the need to be responsive to a rapidly changing environment. The organisations that fall into the Adaptors and Avoiders are in a more or less static position defined by their 'core rigidities' particularly around their product-led approach.

\section{Drivers and inhibitors of the practice of arts organisations that seek to diversify their audiences}

\section{Drivers and inhibitors at a case level}

We first examined the extent to which audience diversification was understood as a key priority of the Australian Asian performing arts festival more broadly, rather than just the individual organisations that contributed to the festival program. To do this we undertook a content analysis of two key strategic documents:

- Guiding Principles document - the one page document which formed the basis of the MOUs between members of the consortium that delivered the Asian performing arts festival; and

- Festival communications and promotional material - the 10-page flyer produced by the consortium for the launch of the festival.

While these were both documents produced in the earliest stages of the festival (and therefore represent the embryonic ambitions of the initiative) a content analysis revealed an ambivalent 
response to audience diversity within the project.

The Guiding Principles reveal the festival's ambitious and innovative intentions. Its vision is for a festival that is, 'creatively focused, collectively driven project responding to the imaginative lives of peoples co-habiting the Asia-Pacific region and the enduring cultural connections of the Australian community with this region'. Included in its strategic statements is a note that the festival, 'is an opportunity for new and surprising outcomes, risk taking and exploration'. However the term 'audience' appears only once in the Guiding Principles: '[the performing arts festival] will reach out to audiences, advocates and participants nationally and internationally'. Cultural production was emphasised in the Guiding Principles, with creative collaborations, cultural exchange and artistic innovation being the festival's priorities. The Guiding Principles suggest an inward facing and productfocused approach, rather than an external interest in audiences.

Conversely the festival handout produced to communicate with stakeholders and investors describes the festival as, 'an ambitious and innovative strategy to build and develop audiences for Asian programming'. The handout acknowledges both Australian and international audiences for the festival, and promises education and community engagement to build local participation and access. Attention to audiences can be seen across the cultural engagement, artistic exchange, and the economic diplomacy aims identified for the festival. The audience development work to be undertaken as part of the festival includes:

- Testing new ways of delivering an innovative arts business model;

- Building and developing new audiences through Asian-Australian artistic exchanges, tours and partnerships; and

- Actively engaging the young Asian populations of Melbourne, including large international student audiences with young, dynamic programming. 
This analysis of the two documents suggest a contradictory approach to audience development that aims to diversify audiences and a distinction between rhetoric (as illustrated in the festival handout) and practice (embodied in the Guiding Principles). According to our typology, the Guiding Principles classify the festival's organising body as an 'Avoider' of the organisational change required to diversify audiences; there is no compelling drive for change and the organiser remains focused on creative practice and production. Conversely, the promotional material would that the festival's organising body is a 'Leader' that seeks to undertake new and innovative practice and secure a different profile of audiences to engage with new and distinctive programming.

The separation between change in rhetoric and change in practice (Suddaby \& Greenwood 2005) means that the organisational change needed to diversify audiences has not been institutionalised; its value is not yet communicated or received as an objective fact (Zucker 1991). Meyer and Rowan (1991) suggest this gap between rhetoric and practice is a 'decoupling' mechanism that enables organisations to separate their formal structures from their actual work, a way of building a myth of their organisation while maintaining traditional practice.

\section{Drivers and inhibitors at an embedded case level}

To determine where individual arts organisations sat in relation to the spectrum of approaches to organisational practice required to diversify audiences, a second phase of research was undertaken. This involved examining two audience diversification case studies: (a) Australian Asian performing arts festival that sought a more culturally diverse audience; and (b) UK learning disability audience diversification initiative. Within each of these case studies individual arts organisations presented embedded case studies (see Table 1). The embedded case studies were examined to determine whether individual organisations could 
be classified as 'Leader', 'Adaptor' or an 'Avoider' at each of the eight steps in the Leading Change for Audience Diversification model. The findings from both case studies are compiled in Figure 1. According to these findings $40 \%$ of the organisations can be classified overall as 'Leaders' in relation to the work undertaken to diversify audiences, with the remaining $60 \%$ falling into the 'Adaptors' category. None of the organisations received an overall assessment as 'Avoiders'.

Insert Figure 1 about here

In summary, areas of strength or greater capacity in relation to the organisational change required to diversify audiences appear to be: awareness of the need for change (step 1), building relationships (step 5) and gaining broad organisational support (step 6) as there was no evidence of Avoiders in these areas of practice. Relative areas of weakness or lower capacity appear to be identifying a target audience (step 2), responsive programming (step 4) and organisational support (step 6), as these presented the least evidence of Leaders. Findings for research barriers (step 3) and reflective practice (step 7) were interesting given the polarised responses; there were equal numbers of Leaders and Avoiders for these aspects of the change model and no evidence of Adaptors.

Comparison of results from the two case studies (see Figures 2 and 3)reveals that both programs support the notion of a spectrum of approaches to the Leading Change for Audience Diversification model, with each providing evidence of Leaders, Adaptors and Avoiders. While the small number of cases mean that statistically the difference between the two programs is not significant, our findings suggest further investigation is warranted into the factors that impact on programs targeting particular groups of non-attenders. 
Insert Figure 2 about here

Insert Figure 3 about here

These findings suggest the value of our Leading Change for Audience Diversification model in describing the organisational change needed to alter the social profile of audiences (particularly in relation to cultural background and learning disability). The findings also indicate our model can identify the range of capacities arts organisations bring to the organisational behaviour required to diversify audiences. Evident in these findings are both the 'core rigidities' on the one hand and the 'dynamic capabilities', identified by Ambrosini and Bowman (2009), which characterise organisations that are grappling with change.

Across both case studies the need to change the social profile of arts audiences appears to be well accepted (step 1). However in the Australian program (the only case study which collected relevant data) there is little evidence of this awareness resulting in fundamental and ongoing change in the practice of arts organisations (step 8). This suggests an incomplete organisational change process (Greenwood, Hinings \& Suddaby 2002). While the external pressure to change practice has been acknowledged (DiMaggio \& Powell 1983), the arts sector is either uncertain of the changes that are required, or these new ways of operating have not been accepted as the 'new normal'. It is clear that the process of achieving broad organisational commitment is not a simple one. The arts organisations which are focused on audience diversification ('Leaders') demonstrate a widely distributed readiness to question the status quo and to trial new approaches underpinned by a commitment to audience diversification as a key strategic objective. 
Identifying new target audiences and forming complex and nuanced understandings of these groups (step 2) was a relative weakness in the work done for both the Australian and UK case studies. It is possible that organisations which are reluctant or unable to undertake organisational change are involved in an 'othering' (Said 1979) of non-arts attenders. An ability to develop dynamic capabilities relevant to the diversification of audiences may require a curiosity about people and those that don't currently engage in the arts rather than dismissing this large part of the general population (Smyth et al. 2004).

Steps 3 to 5 involve dynamic capabilities that focus on social networks and the capacity to build relationships with groups and individuals outside the arts organisation. It is difficult to observe clear trends between the case studies regarding the capacity of arts organisations to build relationships that lead to diverse audiences; while researching barriers to participation is a particular strength of 'Leaders' and work done in the Australian case study there was no evidence of 'Avoiders' focusing on and valuing the building new relationships. One explanation for this lack of clarity in the Australian case is the emphasis in the Guiding Principles on artistic collaborations and creative exchanges identified in Phase 1 of the research. While arts organisations may have had varying capacity to build relationships with new audience groups, they are capable of forming new relationships for the purpose of creative and artistic innovation. The same capacity for collaboration is apparent internally, with no case study organisation exhibiting 'Avoider' behaviour to gaining broad organisational support for work done to diversify audiences (step 6).

A capacity to undertake evaluation and reflective practice (step 7) was a strength exhibited by a number of arts organisations involved in the Australian cultural diversity project. The arts organisations which are focused on audience diversification exhibit dynamic capabilities by using extensive and critical evaluation of audience diversification activities and use the findings to drive new practice. This contrasts with the UK case study where 
evaluation is either used for reporting upwards or is not undertaken at all. The difference between case studies suggests that a capacity for reflective practice may be more aligned with organisations involved in programming.

The overall classification of the embedded case studies examined in this study are presented in Table 4. These findings indicate that four of the case studies were Leaders and six were Adaptors. Two of the Leaders in the Australian case study (CP5 and CP6) were notable as organisations that are not engaged in heritage artforms (i.e. traditional visual and performing arts) and small to medium sized organisations. The third Leader in the Australian case study (CP1) was something of an anomaly in that it programmed play readings and workshops rather than presenting fully developed and staged works. In this manner its programming for the audience cultural diversity initiative was marginalised from its usual offerings. The Leader in the UK case study (DP3) shares the trait of not being wedded to producing canonical works and is an organisation with a strong political and historical identity as rooted in its community. This manifests itself in a strong connection to that community and desire to embrace this in its audiences and programming. These findings suggest that organisations less concerned with traditional artforms or the Western canon may have a greater capacity for organisational change than those with smaller/ medium sized organisational structures. In other words those organisations which were categorised as Leaders may be best placed to act as institutional entrepreneurs; a role associated with organisations that lack resources and located on the periphery of their field due to their perceived lower status (Battilana \& Leca 2009; Battilana, Leca \& Boxenbaum 2009).

The relative absence of Avoiders across the two case studies is worth highlighting. This outcome is likely the result of a research limitation in the form of selection bias; all the embedded case studies voluntarily opted into the audience diversification initiatives that were examined in this research. Organisations that evidence Avoider behaviour, or have low levels 
of capacity for organisational change, are unlikely to display an organisational disposition to voluntarily participate in an audience diversification project.

The Australian and UK case studies present an opportunity to compare the impact of top down and bottom up policy approaches to audience diversification. The UK program was undertaken in a regulatory context involving mandatory reporting of audience statistics, whereas the Australian program occurred in a policy environment which induced organisations to diversify audiences through a range of activity based incentives. While the small number of cases examined in this study limits the generalisability of findings, it appears the Australian approach of incentivising organisations to diversify audiences supports the broader adoption of the organisational practice required to achieve this outcome. Our findings suggest that encouraging organisations to diversify audiences may have led to Australian arts organisations recognising the need for change (step 1), researching audiences and barriers to participation (step 3) and undertaking reflective practice (step 7). Conversely, mandatory reporting of audience statistics may have encouraged UK organisations to identify target audiences (step 2) but undermined their capacity to bring organisation-wide attention to the issue (step 6) or undertake reflective practice (step 7).

Our Leading Change for Audience Diversification model has value for policy development, as it not only outlines the organisational practices required to change the social profile of audiences but identifies a range of organisational responses to this work. The model provides a road map for policy makers seeking to increase the capacity of arts organisations to diversify audiences and thereby: increase the number of arts attenders; deal with issues of social exclusion; increase cultural vitality; and ensure the public value of government funded arts organisations. At the same time our spectrum of approaches identifies the obstacles and resistance organisations may face in implementing the model, given that this form of practice is likely to involve organisational change. Our findings suggest this work is more effectively 
undertaken through policy inducements that encourage and build the capacity of arts organisations than through the use of mandatory measures.

\section{Conclusion}

Our study has examined the strengths and weaknesses of 10 arts organisations participating in audience development initiatives that aimed to change the social profile of audiences by examining their organisational practice through the use ofan audience diversification model. Building on the work of Harlow (2014) this model represents a new conceptualisation of the organisational work that is required if the goal is to diversify arts audiences according cultural background, disability, age, class or geography.

In proposing this new conceptualisation of audience diversification practice our study finds that there are generalizable characteristics for organisations seeking to change the social profile of audiences. Firstly, we have found that there needs to be a catalytic moment, or exogenous 'jolt', which prompts the organisation to see that change is needed. Indeed, organisations have to recognise that it cannot be business-as-usual if the task is to successfully diversify audiences. Secondly, our study finds that the organisations that are more likely to be successful in this task are target-led, rather than product-led. This is problematic for many arts organisations because they may tend to see themselves, intrinsically, in terms of their symbolic assets: the products of the 'brand vision' of the Artistic Director (O'Reilly 2011:49). In our research, the case study organisations that actively seek out new audiences and develop a target-led approach to marketing are more likely to perform well. Thirdly, we have found that the dynamic capabilities of organisations their capacity to find new resources, advocates and networks - is a critical component of the endeavour to reach non-traditional arts audiences. 
Our study identifies that the case study organisations sit along a spectrum of readiness for the change needed to diversify audiences: at one end we find organisations manifesting resistance, some avoiding the necessary steps, and others are (according to our typology) 'Leaders'. The organisations that appear to be the most resistant are receiving or commissioning venues, or larger, artistic program-led organisations that work in heritage artforms (eg classical music and mainstage theatre). The organisations that seem, in our study, to manifest more readiness for change are small to medium sized organisations and multi-artform festivals. We find that longevity does not predict a lack of organisational flexibility, as a number of the Leader organisations have been operating for over 30 years. Instead, organisations that are Leaders in the work needed to diversify audiences are likely to be motivated by a longstanding connection to a community or location, or the desire to be relevant and deliver public value.

This study has tested a spectrum of approaches to organisational change and the diversification of audiences and found that the task of diversifying audiences is a complex one that can be driven or inhibited by particular organisational practices. While cultural policy agencies (like the ACE) prosecute their top-down approach with mandatory reporting on diversity statistics, we urge a simultaneous bottom-up approach which facilitates funded arts organisations to deeply interrogate their approaches and practices in order to embrace and lead change. 


\section{References}

Alvesson, M \& Skoldberg, K 2010, Reflexive Methodology: New vistas for qualitative research, Sage, Thousand Oaks CA.

Ambrosini, V \& Bowman, C 2009, 'What are dynamic capabilities and are they a useful construct in strategic management?', International Journal of Management Reviews, vol. 11, no. 1, pp. 29-49.

Americans for the Arts 2019, Americans for the Arts, retrieved 28 October 2019, <https://www.americansforthearts.org/>.

Arts Council England 2018, Equality, Diversity and the Creative Case: A Data Report, 2016-17, Manchester.

Australia Council for the Arts 2010a, Artistic Vibrancy: A way for organisations to talk about artistic impact, <https://www.australiacouncil.gov.au/artisticvibrancy/>.

Australia Council for the Arts 2010b, Australian Participation in the Arts : More than bums on seats, 9781920784508 (Research report), Sydney.

Australia Council for the Arts 2015, Arts Nation: An Overview of Australian Arts, Sydney.

Australia Council for the Arts 2016, Cultural Engagement Framework, retrieved 29 July 2019,

<https://www.australiacouncil.gov.au/programs-and-resources/cultural-engagement-framework/>

Battilana, J \& Leca, B 2009, 'The role of resources in institutional entrepreneurship: insights for an approach to strategic management that combines agency and institution', in LA Costanzo \& RB MacKay (eds), Handbook of Research on Strategy and Foresight, Edward Elgar, Cheltenham, UK, pp. 260-74.

Battilana, J, Leca, B \& Boxenbaum, E 2009, 'How Actors Change Institutions: Towards a Theory of Institutional Entrepreneurship', Academy of Management Annals, vol. 3, no. 1, pp. 65-107.

Bennett, T \& Frow, J 1991, Art galleries, who goes?: a study of visitors to three Australian art galleries, with international comparisons, Australia Council, Griffith University Institute for Cultural Policy Studies, Redfern, NSW.

Bernstein, JS \& Kotler, P 2006, Arts Marketing Insights : The Dynamics of Building and Retaining Performing Arts Audiences, John Wiley \& Sons, Hoboken.

Boorsma, M 2006, 'A Strategic Logic for Arts Marketing', International Journal of Cultural Policy, vol. 12, no. 1, pp. 73-92.

Bourdieu, P 1984, Distinction: A social critique of the judgement of taste, Harvard University Press, Cambridge MA.

Bovaird, T \& Loeffler, E 2012, 'From Engagement to Co-production: The Contribution of Users and Communities to Outcomes and Public Value', Voluntas: International Journal of Voluntary \& Nonprofit Organizations, vol. 23, no. 4, pp. 1119-38.

Brown, AS 2013, Engaging Next Generation Audiences: A Study of College Student Preferences towards Music and the Performing Arts, Hopkins Center for the Arts, Dartmouth College, New Hampshire.

Brown, AS \& Novak-Leonard, JL 2011, Getting in on the Act: How arts groups are creating opportunities for active participation, James Irvine Foundation, San Franscisco.

Canada Council for the Arts 2016, Shaping a New Future: Strategic Plan 2016-21, Ontario. 
Colbert, F 2003, 'Entrepreneurship and Leadership in Marketing the Arts', International Journal of Arts Management, vol. 6 , no. 1 , pp. 30-9.

Conner, L 2013, Audience engagement and the role of arts talk in the digital era, Palgrave Macmillan, New York.

Creative Europe 2018, ADESTE+: Audience Development strategies for cultural organizations in Europe retrieved November 2019, < http://www.creativeeuropeuk.eu/funded-projects/audience-development-strategies-cultural-organizationseurope>.

Creative New Zealand 2015, Six projects funded to increase diversity in Auckland's arts 5 February, Auckland, <http://www.creativenz.govt.nz/news/six-projects-funded-to-increasediversity-in-auckland-s-arts $>$.

Croggon, A 2016, 'Culture Crisis: The arts funding cuts are just a symptom of a broader malaise in Australia', The Monthly.

den Hertog, P, van der Aa, W \& de Jong, M 2010, 'Capabilities for managing service innovation: towards a conceptual framework', Journal of Service Management, vol. 21, no. 4, pp. 490-514.

Department for Culture, Media and Sport, 2016, The Culture White Paper, London.

DiMaggio, P \& Powell, W 1983, 'The Iron Cage Revisited: Institutional isomorphism and collective reality in organisational fields', American Sociological Review, vol. 48, no. 2, pp. 147-60.

DiMaggio, P \& Useem, M 1978, 'Cultural Democracy in a Period of Cultural Expansion: the social composition of arts audiences in the United States', Social Problems, vol. 26, no. 2, p. 55.

Dubois, A \& Gadde, L-E 2014, '“Systematic combining”-A decade later', Journal of Business Research, vol. 67, no. 6, pp. 1277-84.

Durrer, V \& Miles, S 2009, 'New perspectives on the role of cultural intermediaries in social inclusion in the UK', Consumption, Markets \& Culture, vol. 12, no. 3, pp. 225-41.

Featherstone, M 1991, Consumer Culture and Postmodernism, Sage, Thousand Oaks CA.

Greenwood, R, Hinings, CR \& Suddaby, R 2002, 'Theorising Change: The role of professional associations in the transformation of institutionalised fields', Academy of Management Journal, vol. 45, no. 1, pp. 58-80.

Greenwood, R, Hinings, CR \& Whetten, D 2014, 'Rethinking Institutions and Organizations', Journal of Management Studies, vol. 51, no. 7, pp. 1206-20.

Greer, CR, Lusch, RF \& Vargo, SL 2016, 'A service perspective: Key managerial insights from service-dominant (S-D) logic', Organizational Dynamics, vol. 45, no. 1, pp. 28-38.

Harlow, B 2014, The Road to Results: Effective Practices for Building Arts Audiences, The Wallace Foundation, New York.

Hill, E, O'Sullivan, C, O'Sullivan, T \& Whitehead, B 2018, Creative arts marketing, Routledge, Abingdon.

Holden, J 2006, Cultural Value and the Crisis of Legitimacy: Why culture needs a democratic mandate, Demos, London. 
Kawashima, N 2006, 'Audience Development and Social Inclusion in Britain', International Journal of Cultural Policy, vol. 12, no. 1 , pp. 55-72.

Kemp, E \& Poole, SM 2016, 'Arts Audiences: Establishing a Gateway to Audience Development and Engagement', Journal of Arts Management, Law \& Society, vol. 46, no. 2, pp. 53-62.

Kong, L 2012, 'Ambitions of a global city: arts, culture and creative economy in 'Post-Crisis' Singapore', International Journal of Cultural Policy, vol. 18, no. 3, pp. 279-94.

Kurin, R 1997, Reflections of a culture broker : a view from the Smithsonian, Smithsonian Institution Press, Washington, DC.

Lawrence, TB 1999, 'Institutional Strategy', Journal of Management, vol. 25, no. 2, pp. 161-87.

Lindelof, AM 2015, 'Audience development and its blind spot: a quest for pleasure and play in the discussion of performing arts institutions', International Journal of Cultural Policy, vol. 21, no. 2, pp. 200-18.

Mar, P \& Ang , I 2015, Promoting Diversity of Cultural Expressions in Arts in Australia, Australia Council for the Arts, Sydney.

Mc Carthy, K \& Jinnett, K 2001, A New Framework for Building Participation in the Arts, RAND, Santa Monica, CA.

Meyer, JW \& Rowan, B 1991, 'Institutionalised Organisations: Formal Structure as Myth and Ceremony', in W Powell \& P DiMaggio (eds), The New Institutionalism in Organisational Analysis, University of Chicago Press, Chicago, pp. 43-61.

Moffat, K \& Turpin, R 2018, Art UK - Audience broadening initiative project summary, London.

Moore, M 1995, Creating Public Value: Strategic management in government, Harvard University, Cambridge MA.

Moore, M \& Benington, J 2011, Public Value: Theory and Practice, Palgrave Macmillan, London.

Moore, M \& Moore, G 2005, Creating Public Value Through State Arts Agencies, Arts Midwest, $<$ http://www.wallacefoundation.org/knowledge-center/Pages/Creating-Public-Value-Through-State-Arts-Agencies.aspx>.

National Endowment for the Arts 2015, When Going Gets Tough: Barriers and Motivations Affecting Arts Attendance, NEA Research Report \#59, NEA, Washington.

Ostrower, F 2005, The Diversity of Cultural Participation: Findings from a national survey, Washington.

Parker, S 2012, Building Arts Organisations that Build Audiences, Wallace Foundation, New York.

Pérez-Nordtvedt, L, Kedia, BL, Datta, DK \& Rasheed, AA 2008, 'Effectiveness and efficiency of cross-border knowledge transfer: An empirical examination', Journal of Management Studies, vol. 45, no. 4, pp. 714-44.

Said, EW 1979, Orientalism, Vintage Books, New York.

Smets, M, Morris, T \& Greenwood, R 2012, 'From Practice to Field: A multilevel model of practice-driven institutional change', Academy of Management Journal, vol. 55, no. 4, pp. 877-904. 
Smyth, M, Jennings, M, Bayne, D \& Smyth, S 2004, Not for the likes of you: how to reach a broader audience, Morton Smyth, Edinburgh.

Suddaby, R \& Greenwood, R 2005, 'Rhetorical Strategies of Legitimacy', Administrative Science Quarterly, vol. 50, no. 1, pp. 35-67.

Teece, DJ, Pisano, G \& Shuen, A 1997, 'Dynamic Capabilities And Strategic Management', Strategic Management Journal, vol. 18 , no. 7, pp. 509-33.

UNESCO 2005, Convention on the Protection and Promotion of the Diversity of Cultural United Nations Educational, Scientific and Cultural Organisation, Paris.

UNESCO Institute for Statistics 2009, The 2009 UNESCO Framework for Cultural Statistics, UNESCO, Montreal.

United Nations 2015, Universal Declaration of Human Rights, Geneva, retrieved 5 February 2018, <http://www.un.org/en/udhrbook/pdf/udhr booklet en web.pdf>.

Walmsley, B 2016, 'From arts marketing to audience enrichment: How digital engagement can deepen and democratize artistic exchange with audiences', Poetics, vol. 58, pp. 66-78.

Wensley, R \& Moore, MH 2011, 'Choice and Marketing in Public Management: The creation of public value?', in J Bennington \& MH Moore (eds), Public Value: Theory and Practice, Palgrave Macmillan, Houndsmill, pp. 127-43.

Wiggins, J 2004, 'Motivation, Ability and Opportunity to Participate: A Reconceptualization of the RAND Model of Audience Development', International Journal of Arts Management, vol. 7, no. 1, pp. 22-33.

Yin, RK 2009, Case Study Research: Design and Methods, 4th edn, Sage, Thousand Oaks CA.

Yúdice, G 2018, 'Innovations in cultural policy and development in Latin America', International Journal of Cultural Policy, vol. 24, no. 5, pp. 647-63.

Zucker, L 1991, 'The Role of Institutionalisation in Cultural Practice', in W Powell \& P DiMaggio (eds), The New Institutionalism in Organisational Analysis, The University of Chicago Press, Chicago, pp. 83-107. 
Table 1: Case study design

\begin{tabular}{|c|c|c|c|c|}
\hline \multicolumn{3}{|c|}{ Level of analysis } & Outcome & Data sources \\
\hline \multicolumn{5}{|l|}{ Phase 1} \\
\hline \multicolumn{3}{|c|}{$\begin{array}{l}\text { Abductive analysis of audience diversification case study: } \\
\text { Australian Asian performing arts festival coordinated and } \\
\text { delivered by consortium of arts organisations }\end{array}$} & $\begin{array}{l}\text { Framework of } \\
\text { organisational } \\
\text { practice } \\
\text { required to } \\
\text { diversify } \\
\text { audiences and } \\
\text { identification of } \\
\text { a spectrum of } \\
\text { approaches } \\
\text { (RQ1) }\end{array}$ & $\begin{array}{l}\text { Narrative } \\
\text { interviews } \\
\text { Focus groups } \\
\text { Desk research }\end{array}$ \\
\hline \multicolumn{5}{|l|}{ Phase 2} \\
\hline \multicolumn{3}{|c|}{$\begin{array}{l}\text { Examination of two case studies: } \\
\text { 1. Australian Asian performing arts festival that aimed to } \\
\text { diversify the cultural profile of audiences (providing } \\
\text { six embedded cases); and } \\
\text { 2. UK learning disability audience diversification } \\
\text { initiative that aimed to diversify the learning disability } \\
\text { profile of audiences (providing four embedded cases). }\end{array}$} & $\begin{array}{l}\text { Identification of } \\
\text { drivers and } \\
\text { inhibitors to } \\
\text { organisational } \\
\text { practice that } \\
\text { seeks to } \\
\text { diversify } \\
\text { audiences }\end{array}$ & $\begin{array}{l}\text { Narrative } \\
\text { interviews } \\
\text { Organisational } \\
\text { survey }\end{array}$ \\
\hline \multicolumn{3}{|c|}{ Profile of embedded case studies } & (RQ2) & \\
\hline Codename & Artform & Organisational type & & \\
\hline \multicolumn{3}{|c|}{$\begin{array}{l}\text { Australian Asian performing arts festival - aiming to } \\
\text { diversify cultural profile (CP) of audiences. Embedded cases } \\
\text { selected to represent a range of art forms and organisational } \\
\text { types. }\end{array}$} & & \\
\hline CP1 & $\begin{array}{l}\text { Play reading and } \\
\text { workshop }\end{array}$ & $\begin{array}{l}\text { Major performing arts } \\
\text { organisation }\end{array}$ & & \\
\hline $\mathrm{CP} 2$ & $\begin{array}{l}\text { Film and } \\
\text { orchestral } \\
\text { performance }\end{array}$ & $\begin{array}{l}\text { Major performing arts } \\
\text { organisation }\end{array}$ & & \\
\hline $\mathrm{CP} 3$ & $\begin{array}{l}\text { Contemporary } \\
\text { dance }\end{array}$ & $\begin{array}{l}\text { Small to medium size } \\
\text { performing arts company }\end{array}$ & & \\
\hline $\mathrm{CP} 4$ & $\begin{array}{l}\text { Contemporary } \\
\text { opera }\end{array}$ & $\begin{array}{l}\text { Small to medium size } \\
\text { performing arts company }\end{array}$ & & \\
\hline CP5 & $\begin{array}{l}\text { Contemporary } \\
\text { performance art }\end{array}$ & $\begin{array}{l}\text { Fringe festival } \\
\text { (established over } 30 \\
\text { years) }\end{array}$ & & \\
\hline CP6 & Literary festival & $\begin{array}{l}\text { Literary festival } \\
\text { (established over } 30 \\
\text { years) }\end{array}$ & & \\
\hline \multicolumn{3}{|c|}{$\begin{array}{l}\text { UK learning disability audience diversification initiative - } \\
\text { aiming to diversify the learning disability profile (DP) of } \\
\text { audiences. All participating organisations invited to } \\
\text { participate in research. }\end{array}$} & & \\
\hline DP1 & Theatre & \begin{tabular}{|l|} 
Smaller scale receiving \\
and commissioning venue
\end{tabular} & & \\
\hline DP2 & Theatre & $\begin{array}{l}\text { Larger scale producing } \\
\text { venue }\end{array}$ & & \\
\hline DP3 & Theatre & $\begin{array}{l}\text { Larger scale producing } \\
\text { venue }\end{array}$ & & \\
\hline
\end{tabular}




\begin{tabular}{|l|l|l|l|l|}
\hline DP4 & Performing Arts & $\begin{array}{l}\text { Smaller scale receiving } \\
\text { and commissioning venue }\end{array}$ & & \\
\hline
\end{tabular}

Table 2: Leading Change for Audience Diversification model

\begin{tabular}{|l|l|}
\hline Stage & Activity \\
\hline 1 & Recognising need for change \\
\hline 2 & Identifying a target audience \\
\hline 3 & Researching this audience and their barriers to participation \\
\hline 4 & Programming that is responsive to the target audience \\
\hline 5 & $\begin{array}{l}\text { Developing a relationship with target audience and building multiple connections } \\
\text { between the audience and arts organisation }\end{array}$ \\
\hline 6 & Gaining broad organisational commitment to audience development \\
\hline 7 & Undertaking evaluation and reflective practice \\
\hline 8 & Changing the organisation's usual way of operating \\
\hline
\end{tabular}


Table 3: Evidence of practice identified in the Leading Change for Audience Diversification model

\begin{tabular}{|c|c|c|c|c|c|c|}
\hline \multirow{2}{*}{$\begin{array}{l}\text { Stage in Leading Change for } \\
\text { Audience Diversification model }\end{array}$} & \multicolumn{6}{|c|}{ Evidence of use by embedded case studies } \\
\hline & $\mathrm{CP} 1$ & $\mathrm{CP} 2$ & $\mathrm{CP} 3$ & $\mathrm{CP} 4$ & CP5 & CP6 \\
\hline $\begin{array}{l}\text { 1. Recognise the need for } \\
\text { change }\end{array}$ & $\checkmark$ & & & & $\checkmark$ & $\checkmark$ \\
\hline 2. Identify target audience & $\checkmark$ & & & $\checkmark$ & $\checkmark$ & $\checkmark$ \\
\hline $\begin{array}{l}\text { 3. Research audience and their } \\
\text { barriers to participation }\end{array}$ & & & & & $\checkmark$ & $\checkmark$ \\
\hline $\begin{array}{l}\text { 4. Programming is responsive to } \\
\text { target audience }\end{array}$ & $\checkmark$ & & & & $\checkmark$ & $\checkmark$ \\
\hline $\begin{array}{l}\text { 5. Develop relationship with } \\
\text { target audience and build } \\
\text { multiple connections between } \\
\text { the audience and arts } \\
\text { organisation }\end{array}$ & $\checkmark$ & & & $\checkmark$ & $\checkmark$ & $\checkmark$ \\
\hline $\begin{array}{l}\text { 6ain broad organisational } \\
\text { commitment to audience } \\
\text { development approach }\end{array}$ & & & & & $\checkmark$ & $\checkmark$ \\
\hline $\begin{array}{l}\text { 7. Undertake evaluation and } \\
\text { reflective practice }\end{array}$ & & & & & $\checkmark$ & $\checkmark$ \\
\hline $\begin{array}{l}\text { 8. Change the organisation's } \\
\text { usual way of operating }\end{array}$ & & & & & $\checkmark$ & $\checkmark$ \\
\hline
\end{tabular}


Table 4: Spectrum of approaches to the organisational practice required by the Leading

Change for Audience Diversification model

\begin{tabular}{|c|c|c|c|}
\hline $\begin{array}{c}\text { Stage in Leading change } \\
\text { for audience } \\
\text { diversification process }\end{array}$ & Leader & Adaptor & Avoider \\
\hline $\begin{array}{l}\text { Stage 1: Recognise need } \\
\text { for change }\end{array}$ & $\begin{array}{l}\text { The need to change the } \\
\text { profile of audiences is } \\
\text { profound }\end{array}$ & $\begin{array}{l}\text { Desire for change is not } \\
\text { enough to make real } \\
\text { changes }\end{array}$ & $\begin{array}{l}\text { Thinks audiences are } \\
\text { only motivated by the } \\
\text { artistic offering }\end{array}$ \\
\hline $\begin{array}{l}\text { Stage } 2 \text { : Identify target } \\
\text { audience }\end{array}$ & $\begin{array}{l}\text { Target audience is well } \\
\text { defined, nuanced and } \\
\text { 'problematised' }\end{array}$ & $\begin{array}{l}\text { Homogenous and } \\
\text { simplistic understanding } \\
\text { of the target community }\end{array}$ & $\begin{array}{l}\text { Target audience is not } \\
\text { identified }\end{array}$ \\
\hline $\begin{array}{l}\text { Stage 3: Research } \\
\text { audience and their } \\
\text { barriers to participation }\end{array}$ & $\begin{array}{l}\text { Audience research has } \\
\text { depth, is multifaceted and } \\
\text { cross departmental }\end{array}$ & $\begin{array}{l}\text { Audience research is only } \\
\text { handled by the marketing } \\
\text { department. }\end{array}$ & $\begin{array}{l}\text { The organisation relies } \\
\text { on its current } \\
\text { assumptions about its } \\
\text { audience }\end{array}$ \\
\hline $\begin{array}{l}\text { Stage 4: Programming is } \\
\text { responsive to target } \\
\text { audience }\end{array}$ & $\begin{array}{l}\text { Artistic process involves } \\
\text { audience/ community } \\
\text { engagement }\end{array}$ & $\begin{array}{l}\text { New 'niche' } \\
\text { programming or } \\
\text { repurposing of existing } \\
\text { program }\end{array}$ & $\begin{array}{l}\text { Business as usual and } \\
\text { maintenance of artistic } \\
\text { autonomy }\end{array}$ \\
\hline $\begin{array}{l}\text { Stage 5: Develop } \\
\text { relationship and } \\
\text { connections with target } \\
\text { audience }\end{array}$ & $\begin{array}{l}\text { Multiple entry points for } \\
\text { audiences and strong } \\
\text { networks outside the } \\
\text { organisation. }\end{array}$ & $\begin{array}{l}\text { The relationship with the } \\
\text { target audience is limited } \\
\text { and not explicitly } \\
\text { nurtured. }\end{array}$ & $\begin{array}{l}\text { Organisation connects } \\
\text { with its audience only } \\
\text { through the box office. }\end{array}$ \\
\hline $\begin{array}{l}\text { Stage 6: Gain broad } \\
\text { organisational } \\
\text { commitment to audience } \\
\text { development }\end{array}$ & $\begin{array}{l}\text { Audience diversification } \\
\text { is a key strategic } \\
\text { objective }\end{array}$ & $\begin{array}{l}\text { Audience diversification } \\
\text { is siloed into one part of } \\
\text { the organisation }\end{array}$ & $\begin{array}{l}\text { No strategic commitment } \\
\text { to audience development }\end{array}$ \\
\hline $\begin{array}{l}\text { Stage 7: Undertake } \\
\text { evaluation and reflective } \\
\text { practice }\end{array}$ & $\begin{array}{l}\text { Extensive and critical } \\
\text { evaluation of audience } \\
\text { development work is } \\
\text { used to drive new } \\
\text { practice }\end{array}$ & $\begin{array}{l}\text { Evaluation is used for } \\
\text { reporting upwards and } \\
\text { doesn't lead to } \\
\text { organisational change }\end{array}$ & $\begin{array}{l}\text { No evaluation undertaken } \\
\text { or it is tokenistic }\end{array}$ \\
\hline $\begin{array}{l}\text { Stage } 8 \text { : Change the } \\
\text { organisation's usual way } \\
\text { of operating }\end{array}$ & $\begin{array}{l}\text { Accept that diversifying } \\
\text { audiences means work } \\
\text { won't be 'business as } \\
\text { usual' }\end{array}$ & $\begin{array}{l}\text { Token gesture change } \\
\text { which is temporary or } \\
\text { short-term. }\end{array}$ & $\begin{array}{l}\text { No change to } \\
\text { organisational practice }\end{array}$ \\
\hline
\end{tabular}




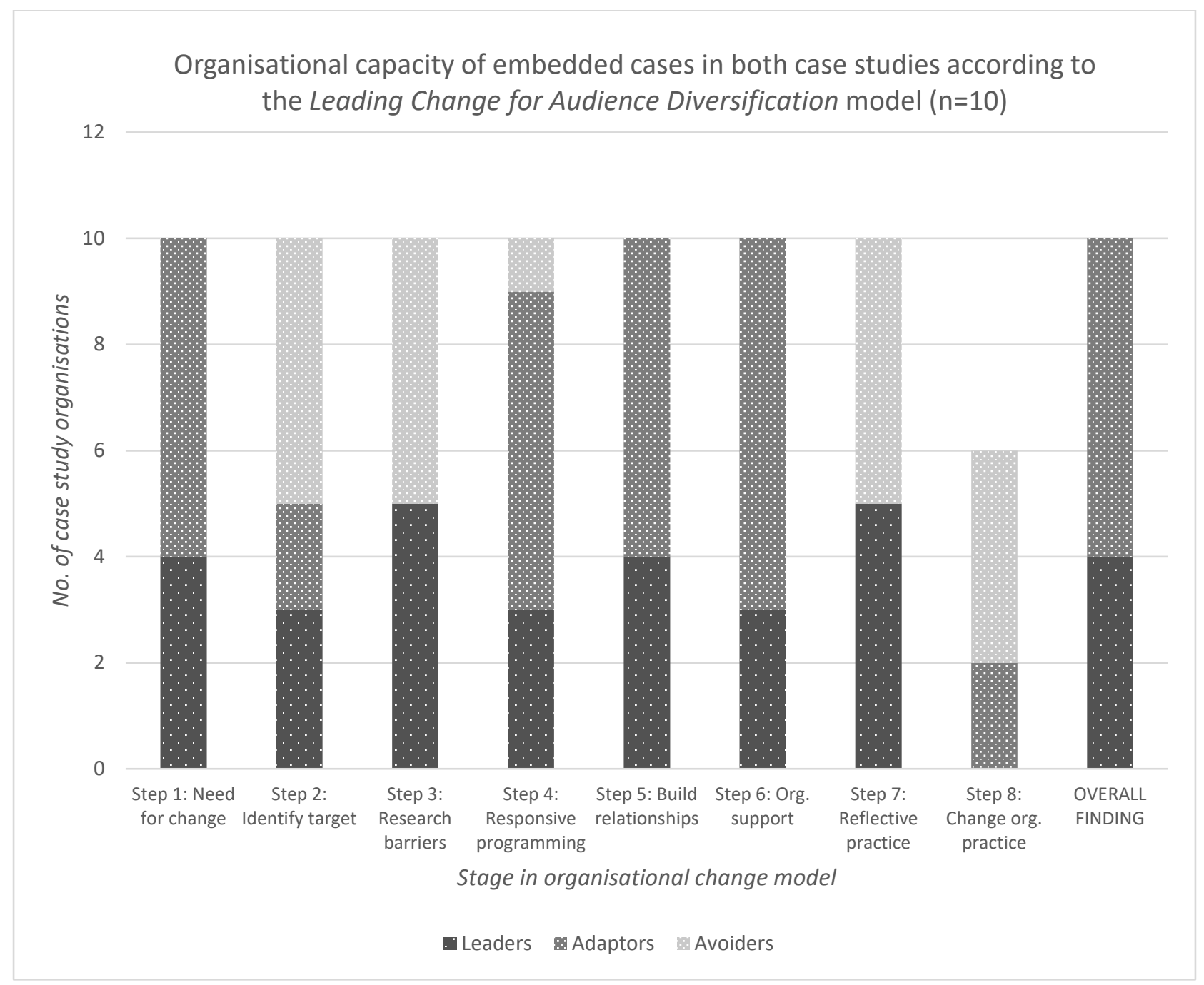

Figure 1: Organisational survey results (Australian Asian performing arts festival and UK disability audience development case studies combined $)^{1}$ 


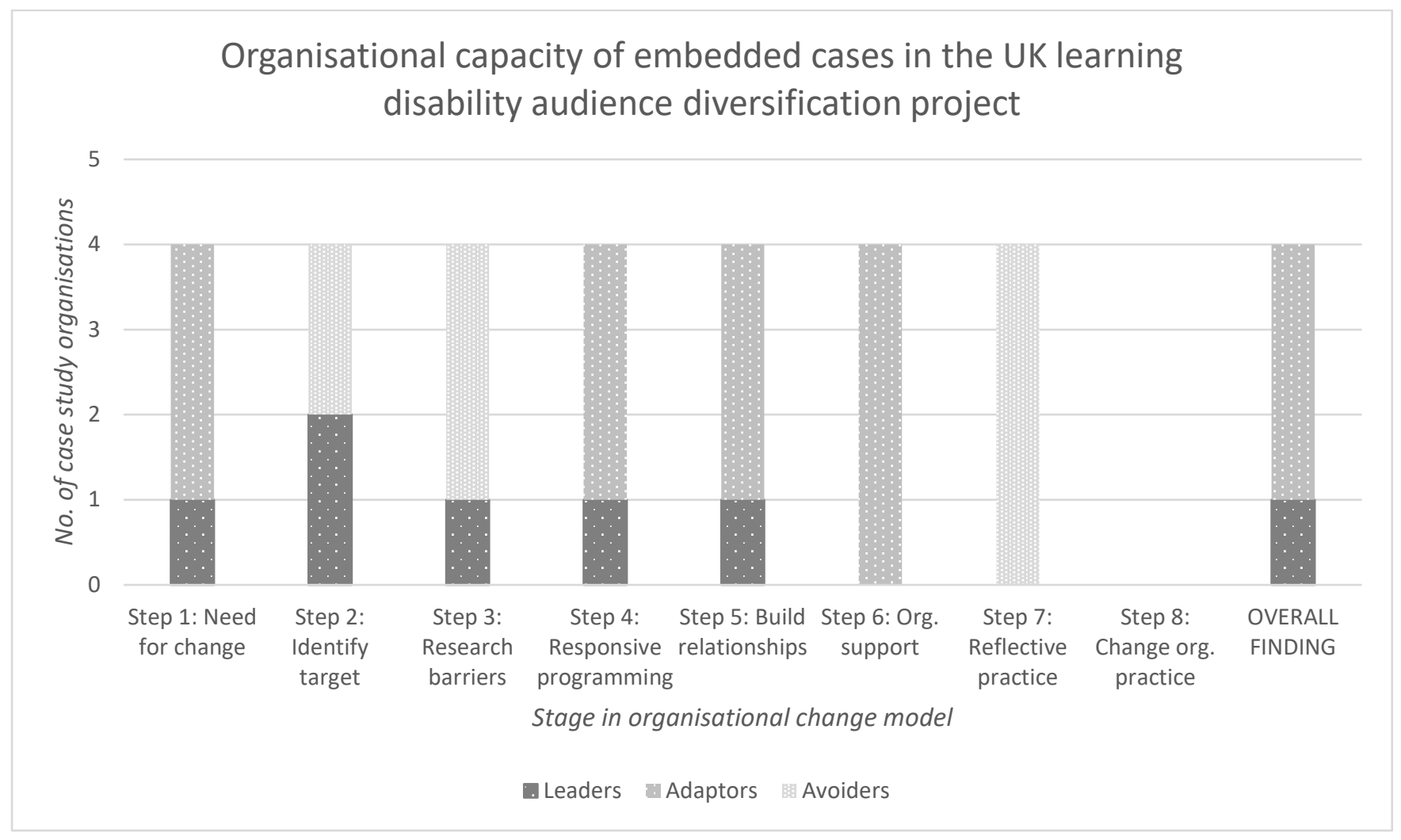

Figure 2 Survey results from organisations that aimed to diversify the learning ability of audiences

\footnotetext{
${ }^{1}$ Survey data collected for the UK audience development initiative did not include step 8 Change organisational practice. This was due to the timelines for the administration of the survey, which was conducted before there was an opportunity to reflect on strategic or operational change within the embedded case studies.
} 


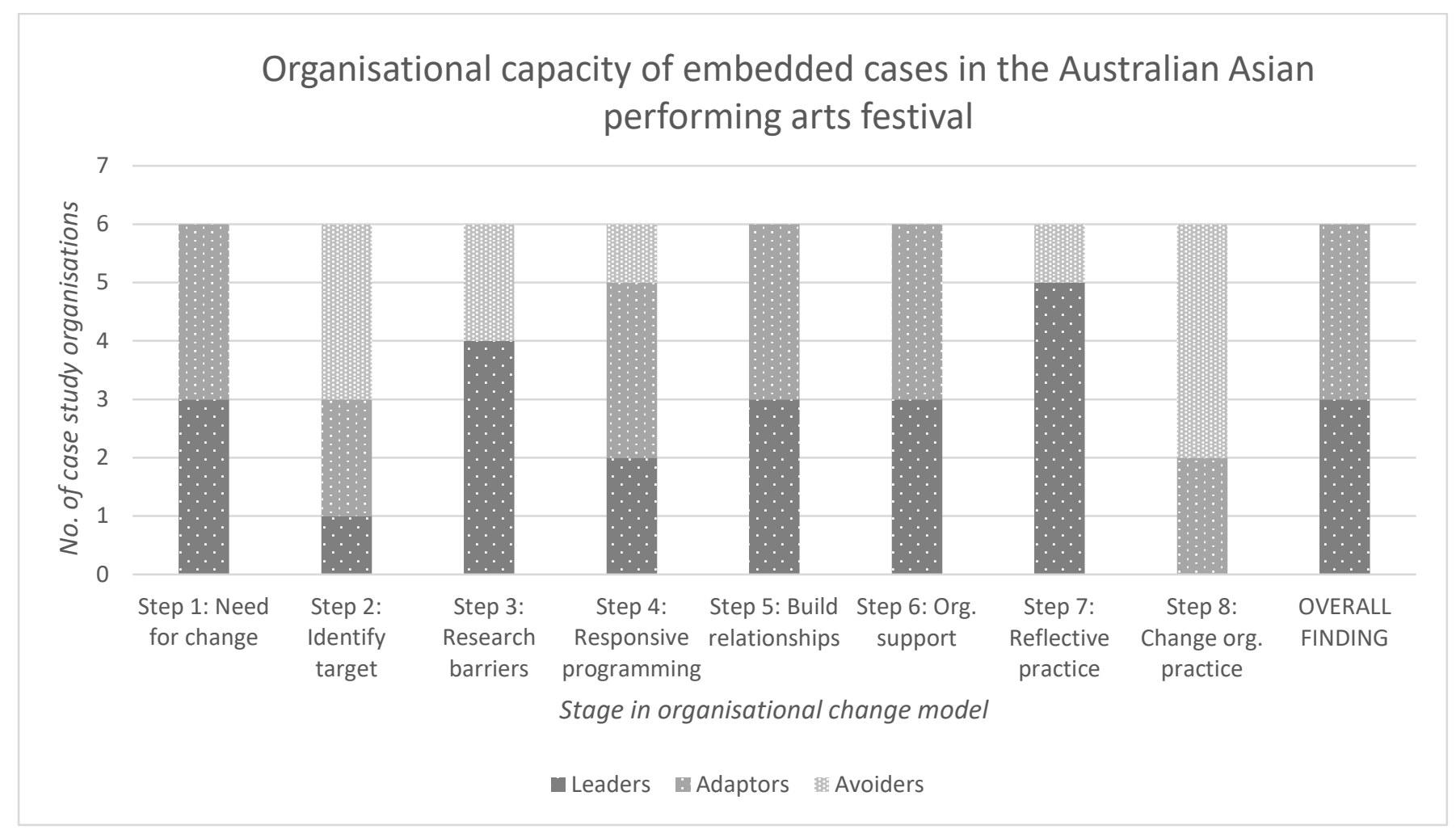

Figure 3: Survey results from organisations that aimed to culturally diversify audiences 
Table 5: Overall assessment of organisations in relation to the Leading Change for Audience Diversification model

\begin{tabular}{|c|c|c|c|}
\hline Codename & Artform & Organisational type & $\begin{array}{l}\text { Overall position on } \\
\text { Leading Change } \\
\text { spectrum }\end{array}$ \\
\hline \multicolumn{4}{|c|}{ Asian performing arts festival - aiming to diversify cultural profile $(\mathrm{CP})$ of audiences } \\
\hline CP1 & $\begin{array}{l}\text { Play reading and } \\
\text { workshop }\end{array}$ & $\begin{array}{l}\text { Major performing arts } \\
\text { organisation }\end{array}$ & Leader \\
\hline CP2 & $\begin{array}{l}\text { Film and orchestral } \\
\text { performance }\end{array}$ & $\begin{array}{l}\text { Major performing arts } \\
\text { organisation }\end{array}$ & Adaptor \\
\hline CP3 & Contemporary dance & $\begin{array}{l}\text { Small to medium size } \\
\text { performing arts company }\end{array}$ & Adaptor \\
\hline CP4 & Contemporary opera & $\begin{array}{l}\text { Small to medium size } \\
\text { performing arts company }\end{array}$ & Adaptor \\
\hline CP5 & $\begin{array}{l}\text { Contemporary } \\
\text { performance art }\end{array}$ & $\begin{array}{l}\text { Fringe festival (established } \\
\text { over } 30 \text { years ago). Small to } \\
\text { medium sized organisation. }\end{array}$ & Leader \\
\hline CP6 & Literary festival & $\begin{array}{l}\text { Literary festival (established } \\
\text { over } 30 \text { years ago). Small to } \\
\text { medium sized organisation. }\end{array}$ & Leader \\
\hline \multicolumn{4}{|c|}{$\begin{array}{l}\text { Audience development initiative - aiming to diversify the learning disability profile (DP) of } \\
\text { audiences. }\end{array}$} \\
\hline DP1 & Theatre & $\begin{array}{l}\text { Smaller scale receiving and } \\
\text { commissioning venue }\end{array}$ & Adaptor \\
\hline DP2 & Theatre & Larger scale producing venue & Adaptor \\
\hline DP3 & Theatre & Larger scale producing venue & Leader \\
\hline DP4 & Performing Arts & $\begin{array}{l}\text { Smaller scale receiving and } \\
\text { commissioning venue }\end{array}$ & Adaptor \\
\hline
\end{tabular}

